\title{
UPAYA HUKUM PENYELESAIAN SENGKETA ANTARA KONSUMEN DENGAN PENGEMBANG PT. NAJAH BINTANG SEJAHTERA DI KOTA PEKANBARU
}

\author{
Dwi Weka Wirawan \\ Universitas Andalas, dwiwekawirawan@gmail.com \\ Yulfasni \\ Universitas_Andalas,yulvgmo@yahoo.com \\ Yussy Adelina Mannas \\ Universitas.Andalas,yussymannas@yahoo.com
}

Diterima: 3 Maret 2019

Direvisi : 20 Mei 2019

Diterbitkan: 30 Juni 2019

\begin{abstract}
House buying and selling is very vulnerable and problems often occur to cause disputes, This research was conducted in an empirical juridical way, the nature of descriptive analysis was by qualitative data analysis, The absence of consumer understanding of the buying and selling process in a contract carried out with the developer and there are still those who do not understand the contents of a contract and there are still developers with consumers making agreements under the hand that are not in accordance with the Laws and Regulations, Housing developers must be responsible for losses suffered by consumers, The legal effort that can be made by consumers is by taking a solution in a way outside the court of non-litigation and litigation through the general court, Consumer dispute resolution is first resolved by means of consensus agreement or peacefully if there is no further settlement, it can be done through a way of settlement outside the court (non litigation) or through a public court (litigation) either civil or criminal.
\end{abstract}

Keywords: House Developers, Completion of Law, Agreement.

\begin{abstract}
Abstrak
Jual beli rumah sangat rawan dan sering terjadi permasalahan hingga menimbulkan sengketa, Penelitian ini dilakukan dengan cara yuridis empiris, sifat penelitian deskriptif analisis dengan analisa data secara kualitatif, Tidak adanya pemahaman konsumen atas proses jual beli dalam suatu kontrak yang dilakukan dengan pengembang dan masih ada yang tidak paham isi dari suatu kontrak dan masih ada pengembang dengan konsumen membuat perjanjian dibawah tangan yang isinya tidak sesuai dengan Peraturan Perundang-Undangan, pengembang perumahan wajib bertanggung jawab dari kerugian yang diderita oleh konsumen. Upaya bukum yang dapat dilakukan konsumen yaitu dengan menempuh penyelesaian dengan cara diluar pengadilan nonlitigasi dan litigasi melalui peradilan umum, Penyelesaian sengketa konsumen terlebih dabulu diselesaikan dengan cara musyawarah mufakat atau secara damai jika tidak ada penyelesaian selanjutnya dapat dilakukan melalui cara penyelesaian di luar pengadilan (non litigasi) atau melalui peradilan umum (litigasi) baik secara perdata maupun pidana.
\end{abstract}

Kata Kunci : Pengembang Perumahan, Upaya Hukum, Perjanjian.

\section{PENDAHULUAN}

Pada dasarnya tidak setiap orang dapat mendapatkan tempat tinggal sendiri dan membangun rumah tempat tinggalnya, karena untuk mendirikan rumah untuk ditempati setiap orang harus memiliki seperti tanah, struktur bangunan, dan izin-izin dari pihak perizinan pendirian pembangunan. Mengingat masyarakat yang masih banyak membutuhkan rumah dan mereka yang keterbatasan 
penghasilannya maka cara yang sering dipilih oleh masyarakat dalam rangka membeli rumah dengan sistem angsuran seperti cash bertahap yang difasilitasi oleh pengembang perumahan.

Perjanjian pendahuluan jual beli rumah (PPJB) pedoman tentang pembuatan perjanjian pengikatan jual beli diatur dalam Keputusan Menteri Negara Perumahan Rakyat Nomor 09/ KPTS / M/ 1995 tentang Pedoman Pengikatan Jual Beli Rumah selanjutnya disebut Kepmenpera No.09/KPTS/M/1995.

Secara khusus pengaturan tentang hak atas properti dapat ditemukan dalam Hukum yang berhubungan dengan perumahan telah diatur dalam Undang-Undang Nomor 1 Tahun 2011 tentang Perumahandan Kawasan Pemukiman. ${ }^{1}$ Hak konsumen dan kewajiban pihak pengembang dalam hal perjanjian juga diatur secara khusus pada UU PKP dalam BAB XIII tentang adanya larangan pada Pasal 134 dikatakan bahwa setiap orang dilarang menyelenggarakan pembangunan Perumahan yang tidak membangun Perumahan sesuai dengan kriteria, spesifik, persyaratan, prasarana, sarana, dan untilitas umum yang diperjanjikan.

Seperti pada Perumahan Najah Dwi Sejahtera PT. Najah Bintang Sejahtera yang beralamat di jalan Kayu Manis (Subrantas) No.39 Tampan Pekanbaru dan sekarang telah pindah alamat di jalan Pemuda I Gg. Maju No. 2 kecamatan Tampan kota pekanbaru merupakan kantor dan tempat kegiatan pemasaran Perumahan Najah Dwi Sejahtera yang lokasi alamat perumahan di jalan sikumbang jati, kecamatan Tampan Kota Pekanbaru, dalam hal Permasalahan yang terjadi seperti pada di Perumahan Najah Dwi Sejahterakepada konsumen, bahwa konsumen membuat kesepakatan dengan pengembang untuk membeli salah satu rumah dengan

\footnotetext{
1 Ahmadi Miru dan Sutarman Yudo, Hukum Perlindungan Konsumen, Jakarta: PT. Raja Grafindo Persada, 2011), 4.
}

sistem cash bertahap kepada pihak pengembang perumahan dan pihak pengembang membuat perjanjian dengan konsumen yang dibuat oleh pihak pengembang Perumahan Najah Dwi Sejahtera. Setelah berjalannya waktu ketika telah dilakukan perjanjian pihak konsumen menanyakan akan rumah yang diperjanjikan akan dibangun oleh pihak Perumahan belum juga dibangun oleh pihak pengembang dan ada juga yang telah dibangun oleh pengembang dan tidak selesai dibangun oleh pihak pengembang sementara uang angsuran pembangunan telah dilunasi sehingga dalam hal ini menimbulkan permasalahan pihak pengembang perumahan yang tidak menepati janji-janji kepada pihak konsumen. Hal tersebut awalnya dengan Pemasaran yang dilakukan pengembang Perumahan sangat tensidius sehingga tidak jarang informasi yang disampaikan itu ternyata menyesatkan (misleading Information) atau tidak benar, padahal konsumen sudah terlanjur menandatangani Perjanjian dengan pengembang. ${ }^{2}$

Artikel penelitian ini terfokus untuk mengetahui pelaksanaan transaksi jual beli rumah yang dilakukan oleh konsumen dan pengembang PT. Najah Bintang Sejahtera di Kota Pekanbaru. Kedua, Untuk mengetahui pertanggungjawaban pengembang terhadap perjanjian jual beli rumah antara konsumen dengan PT. Najah Bintang Sejahtera di Kota Pekanbaru. Ketiga Untuk mengetahui upaya penyelesaian sengketa jika pihak pengembang PT. Najah Bintang Sejahtera tidak memenuhi kewajibannya.

\section{METODE PENELITIAN}

Metode penelitian yang digunakan untuk membahas permasalahan yang terdapat dalam penelitian ini Penulis menggunakan pendekatan yuridis empiris. Adalah suatu

2 Yusuf Shofie, Perlindungan Konsumen dan Instrumen Hukumnya, (Bandung: PT. Citra Aditya Bakti, 2008), 21 
metode penelitian hukum yang berfungsi untuk melihat hukum dalam artian nyata dan meneliti bagaimana bekerjanya hukum di lingkungan masyarakat. Dikarenakan dalam penelitian ini meneliti orang dalam hubungan hidup di masyarakat maka metode penelitian yuridis empiris dapat dikatakan sebagai penemuan hukum sosiologis. Dalam menentukan Sampel penulis menggunakan metode purposive sampling. Mengingat besar dan luasnya populasi maka dalam mengumpulkan data penelitian ini untuk dijadikan sampeldengan menetapkan syaratsyarat tertentu.untuk menentukan sampel penelitian yaitu sampel yang dipilih berdasarkan pertimbangan atau penelitian subyektif dari Peneliti. ${ }^{3}$

Konsumen Perumahan Najah Dwi Sejahtera pada PT. Najah Bintang Sejahtera yang dijadikan responden dalam penelitian ini adalah konsumen yang pernah dirugikan dan yang sedang melakukan penyelesaian sengketa konsumen dengan pengembang Perumahan Najah Dwi Sejahtera pada PT. Najah Bintang Sejahtera. Pengolahan data yang Penulis gunakan adalah dengan sistem editing yaitu dengan memilah data-data berdasarkan kebutuhan dan menyusun secara sistematis data-data yang sudah diperoleh untuk kemudian disajikan secara lengkap dan sempurna, sehingga dapat mempermudah analisis terhadap data-data tersebut dan Data yang diolah kemudian akan dianalisis secara kualitatif yang bersifat yuridis, yaitu tidak menggunakan angka-angka (tidak menggunakan rumus matematika). Kemudian Data yang telah disajikan dianalisis secara kualitatif yaitu uraian yang dilakukan terhadap data yang terkumpul dengan tidak menggunakan angka dan rumus statistik namun berupa kalimat berdasarkan Peraturan Perundang-Undangan, teori, pndangan ahli,

\footnotetext{
${ }^{3}$ Zainuddin Ali, Metode Penelitian Hukum, (Jakarta: Sinar Grafika, 2014), 98
}

dan termasuk pengalaman penelitian. Metode penarikan kesimpulan yang dilakukan dalam penelitian ini adalah metode deduktif yang menyimpulkan dari hal-hal yang bersifat umum kepada hal-hal yang bersifat khusus.

\section{PROSES TRANSAKSI JUAL BELI ANTARA KONSUMEN DENGAN PENGEMBANG PERUMAHAN PT. NAJAH BINTANG SEJAHTERA DI KOTA PEKANBARU.}

Berdasarkan hasil penelitian pada proses transaksi jual belitanah dan rumah penulis temui dilapangan yang dilakukan pada salah satu pihak pengembang perumahan yaitu PT. Najah Bintang Sejahtera di Kota Pekanbaruadanya perjanjian antara pihakpengembang dengan konsumen, bahwa berdasarkan wawancara yang dilakukan dengan bapak Defizul, S.Ag selaku direktur PT. Najah Bintang Sejahtera pada dasarnya melakukan sistem jual beli tanah dan rumah dengan dua cara.

Pertama dengan cara Tunai Langsung yaitu pembayaran yang dilakukan dengan membayar seluruh harga jual unit rumah pada awal perjanjian dan apabila konsumen menggunakan dengan cara ini maka PT. Najah Bintang Sejahtera akan memberikan bonus hadiah dan potongan harga.

Kedua dengan cara Tunai Bertahap/Cash Bertahap yaitu pembayaran tunai langsung dengan sistem bertahap memberikan pembayaran kepada PT. Najah Bintang Sejahtera dengan cara disepakatinya berdasarkan pelaksanaan pembangunan unit rumah yang telah dibeli konsumen. ${ }^{4}$

Dalam hal ini dimana rumah yang belum dibangun dan hanya baru objek tanah saja yang tersedia dan setelah adanya kesepakatan yang diperjanjikan antara pihak penyelenggara perumahan atau pengembang perumahan dengan konsumen maka pihak

\footnotetext{
${ }^{4}$ Defizul, Direktur Utama PT.Najaha Bintang Sejahteraha, Wawancara, pada hari Selasa Tanggal 17 Juli 2018 pukul $14.00 \mathrm{WIB}$
} 
perumahan akan membangun rumah tersebut berdasarkan tipe atau jenis rumah yang telah disepakati yang mana pihak pengembang dengan konsumen dengan menuangkan kesepakatannya di dalam didalam isi perjanjian pengikatan jual beli (PPJB). ${ }^{5}$

Sebelum membuat kesepakatan pembangunan rumah pengembang Perumahan akan meminta persyaratan dan dokumen identitas konsumen, adapun data-data yang diminta oleh pihak Perumahan yaitu:

1. Fotokopi identitas diri Kartu Tanda Penduduk (KTP) suami dan istri (bagi yang sudah menikah) 4 lembar.

2. Fotokopi Kartu Keluarga (KK) 4 lembar.

3. Fotokopi Surat Nikah bagi yang sudah Menikah 4 rangkap.

4. Slip Gaji 3 bulan terakhir 2 rangkap.

5. Surat keterangan bekerja dari perusahaan.

Proses jual beli rumah antara konsumen dengan pengembang perumahan PT. Najah Bintang Sejahtera diketahui melakukan suatu kontrak perjanjian jual beli rumah terlebih dahulu secara dibawah tangan. Perjanjian jual beli rumah tersebut yang berbentuk baku dan memuat isi klausul tentang aturan yang dibuat oleh pihak PT. Najah Bintang Sejahtera, yaitu isinya tentang; Jual beli rumah; Harga jual rumah; Sistem pembayaran; Spesifikasi rumah; dan Serah terima rumah. ${ }^{6}$

Di sinilah awal permasalahan bahwa pihak pengembang perumahan PT. Najah Bintang Sejahtera membuat surat perjanjian di bawah tangan yang isi dari perjanjian tersebut dibuat oleh pengembang perumahan mengenai perjanjian jual beli yang di buat dibawah tangan. Jika melihat dari surat perjanjian tersebut bahwa perjanjian tersebut belum dikatakan telah terjadinya suatu jual beli secara

\footnotetext{
${ }^{5}$ Andika Wijaya dan Wida Peace Ananta, Hukum Bisnis Properti di Indonesia, (Jakarta: PT. Grasindo, 2017), 249.

${ }^{6}$ Defizul, Wawancara, pada hari Selasa Tanggal 17 Juli 2018 pukul 14.00 WIB.
}

tunai, terang dan rii. Bahwa diketahui hal tersebut bukanlah merupakan perjanjian jual beli tanah dan rumah secara riil dikarenakan bahwa sifat dalam jual beli yang diatur dalam KUHPerdata bersifat obligator, bahwa perjanjian jual beli baru meletakkan hak dan kewajiban timbal balik antara kedua belah pihak penjual dan pembeli. Yaitu meletakkan kepada penjual kewajiban untuk menyerahakan hak milik atas barang yang dijualnya sekaligus memberikan kepadanya hak untuk mendapat pembayaran harga yang telah disetujui. Di sisi lain meletakkan kewajiban kepada pembeli untuk membayar harga barang, sesuai imbalan haknya untuk menuntut penyerahan hak milik atas barang yang dibelinya dan bahwa hak milik atas barang yang dijual tidaklah berpindah kepada pembeli selama penyerahannya belum dilakukan.

Jika diperhatikan dari perjanjian tersebut bahwa surat perjanjian tersebut adalah merupakan perjanjian pendahuluan jual beli rumah yang dibuat secara di bawah tangan dan dilakukan dengan sistem cash bertahap yaitu Tunai bertahap/cash bertahap dengan pembayaran tunai langsung dengan sistem bertahap memberikan pembayaran kepada PT. Najah Bintang Sejahtera dengan cara disepakatinya berdasarkan pelaksanaan pembangunan unit rumah yang telah dibeli konsumen.

Perbuatan hukum seperti jual beli adalah salah satu cara untuk mendapatkan tanah dan rumah yang diinginkan sesuai dengan tipe dan kondisi keuangan yang dimiliki masyarakat. Ekonomi yang baik dari masyarakat membuat daya beli masyarakat yang dalam hal ini berperan sebagai konsumen mempunyai kemauan dan kemampuan untuk memperoleh tempat tinggal yang lebih baik lagi. Konsumen adalah "pengguna akhir" (end user) dari suatu produk, yaitu setiap pemakai barang dan jasa yang tersedia dalam masyarakat, baik bagi kepentingan diri sendiri, 
keluarga, orang lain, maupun makhluk hidup lain dan tidak untuk diperdagangkan. ${ }^{7}$

Adanya larangan terhadap pihak pengembang dalam hal perjanjian juga diatur secara khusus pada UU PKP dalam BAB XIII tentang adanya larangan pada Pasal 134 dikatakan bahwa setiap orang dilarang menyelenggarakan pembangunan Perumahan yang tidak membangun Perumahan sesuai dengan kriteria, spesifik, persyaratan, prasarana, sarana, dan untilitas umum yang diperjanjikan.

Dari bunyi pasal tersebut setiap orang baik perorangan maupun berbadan hukum dilarang membangun perumahan yang tidak sesuai dengan yang telah diperjanjikan antara pengembang perumahan kepada konsumen. ${ }^{8}$

TANGGUNG JAWAB PENGEMBANG SEBAGAI UPAYA PERLINDUNGAN KONSUMEN DALAM PENYELENGGARAAN PERUMAHAN DI KOTA PEKANBARU.

Adanya tanggung jawab bagi pihak pengembang perumahan dari isi perjanjian terhadap konsumennya apabila pihak pengembang perumahan tidak melaksanakan perjanjian tersebut sebagaimana yang dikatakan pada Pasal 1365 KUH Perdata bahwa:

"Tiap perbuatan melawan hukum yang membawa kerugian kepada orang lain mewajibkan orang karena salahnya menerbitkan kerugian itu, mengganti kerugian tersebut."

Pada Pasal 129 huruf (a) UndangUndang Perumahan dan Permukiman menyebutkan bahwa:

"Dalam penyelenggaraan Perumahan dan kawasan Permukiman Setiap orang berhak menempati, menikmati, dan/atau

7 Munir Fuady, Pengantar Hukum Bisnis Menata Bisnis Modrn di Era Global, (Bandung: Citra Aditya Bakti, 2013), 227.

8 M. Sadar, Moh. Taufik Makarao, Habloel Mawardi, Hukum Perlindungan Konsumen di Indonesia, (Jakarta: Akademia, 2012), 2 memiliki, memperoleh rumah yang layak dalam lingkungan yang sehat, aman, serasi, dan teratur".

Sebagaimana yang disebutkan Pasal 50 Ayat (1) UU PKP bahwa setiap orang berhak untuk bertempat tinggal atau menhuni rumah.

Dari bunyi Pasal tersebut maka jelas bahwa perumahan yang dibangun oleh pengembang Perumahan menjadi hak setiap orang untuk menempati, menikmati dan memiliki bagi setiap orang. Pasal 129 UndangUndang Perumahan dan kawasan Permukiman, karena hal ini mutlak menjadi tanggung jawab pelaku usaha yaitu pengembang Perumahan untuk menempatinya sehingga terpenuhinya hak konsumen untuk menempati, menikmati dan memiliki rumah.

Sebagaimana tanggung jawab pelaku usaha dalam hal ini pengembang perumahan yang telah diatur dalam Pasal 19 UUPK Disebutkan bahwa:

1. Pelaku usaha bertanggung jawab memberikan ganti rugi atas kerusakan, pencemaran, dan/atau kerugian konsumen akibat mengkonsumsi barang dan/atau jasa yang dihasilkan atau diperdagangkan.

2. Ganti rugi sebagaimana dimaksud pada Ayat (1) dapat berupa pengembalian uang atau penggantian barang dan/atau jasa yang sejenis atau setara nilainya atau perawatan kesehatan dan/atau pemberian santunan yang sesuai dengan ketentuan PeraturanPerundang-Undangan yang berlaku.

3. Pemberian ganti rugi dilaksanakan dalam tenggang waktu 7 (tujuh) hari setelah tanggal transaksi.

4. Pemberian ganti rugi sebagaimana dimaksud pada Ayat (1) dan Ayat (2) tidak menghapuskn kemungkinan adanya tuntutan pidana berdasarkan pembuktian lebih lanjut mengenai adanya unsur kesengajaan. 
5. Ketentuan sebagaimana dimaksud pada Ayat (1) dan Ayat (2) tidak berlaku apabila pelaku usaha dapat membuktikan bahwa kesalahan tersebut merupakan kesalahan konsumen.

Berdasarkan ketentuan tersebut di atas dapat diketahui bahwa pengembang PT. Najah Bintang Sejahtera bertanggung jawab untuk memberikan ganti rugi kepada konsumen apabila konsumen menderita atau mengalami sesuatu yang tidak menyenangkan akibat mengkonsumsi barang dan atau jasa yang dibeli dari pelaku usaha. Ketentuan tersebut di atas sebenarnya merupakan ketentuan yang masih bersifat umum. Apabila dikaitkan dengan masalah terhadap konsumen di bidang Perumahan, maka ketentuan tenggang waktu pemberian ganti rugi tersebut di atas tidak mungkin dapat dilaksanakan. Namun demikian mengenai tanggung jawab ganti rugi bagi pelaku usaha (pengembang Perumahan) dapat pula diterapkan bagi pelaku usaha (pengembang Perumahan) yang merugikan konsumennya.

Dari hasil penelitian diketahui bahwa adanya permasalahan dari tidak terbangunnya dan tidak terselesaikannya rumah konsumen menjadi tanggung jawab pengembang Perumahan PT. Najah Bintang Sejahtera kepada konsumen. Hal tersebut sebenarnya tidak hanya terpaku pada isi perjanjian Jual beli saja, tetapi secara umum tanggung jawab pengembang Perumahan sudah ada sejak pengembang Perumahan ingin membangun rumah, namun dari tanggung jawab tersebut masih banyak faktor kendala-kendala yang dihadapi oleh pihak pengembang Perumahan seperti:

1. Kendala dari biaya pembangunan rumah yang tidak mencukupi.

2. Kendala pekerja pembangunan rumah yang tidak selesai tepat waktu.

3. Kendala bahan bangunan yang harganya naik dan
4. Kendala teknis pada proses perizinan. ${ }^{9}$

Dari hasil penelitian konsumen mengatakan bahwa Tanggung jawab dari pihak pengembang perumahan PT. Najah Bintang Sejahtera hanya sebatas janji-janji saja, pertanggung jawaban atas ketidak jelasanya dibangunnya unit rumah yang sebagimana diperjanjikan dan disepakati oleh pihak Perumahan dan konsumen tidak ada kejelasan dari pihak pengembang Perumahan. Sehingga hal ini menjadi kerugian materil oleh konsumen yang tidak sedikit, hingga saat ini uang sudah diberikan namun rumah tidak dibangun oleh pihak pengembang dan rumah yang dijanjikan oleh pengembang tersebut sekarang telah dijual oleh pihak pengembang kepada pihak lain. ${ }^{10}$ Dalam KUHPerdata Pasal 1365-1367 prinsip tanggung jawab berdasararkan kesalahan sangat jelas dalam Pasal ini. Prinsip ini menyatakan seseorang baru dapat dimintakan pertanggung jawabannya secara hukum jika ada unsur kesalahan yang dilakukan. ${ }^{11}$

Tidak ada tanggung jawab dari pihak pengembang perumahan terhadap konsumen dari kesepakatan dan perjanjian yang di janjikan oleh pihak pengembang perumahan sehingga hak konsumen tidak terpenuhi dan kewajiban pihak pengembang perumahan tidak dilaksanakan. Pihak pengembang perumahan tidak mempunyai tanggung jawab dalam melaksanakan kewajibannya padahal Konsumen sudah memberikan uang muka dan uang angsuran pembangunan rumah tetapi pihak pengembang Perumahan tidak memberikan kejelasan juga rumah yang telah disepakati kepada konsumen.

Berdasarkan hasil penelitian penulis lakukan dengan pihak pengembang

${ }^{9}$ Defizul, Wawancara, pada hari Selasa Tanggal 17 Juli 2018 pukul 14.00 WIB.

${ }^{10}$ Hendri Yofi, Konsumen Perumahan Najah Dwi Sejahtera PT. Najah Bintang Sejahtera, Wawancara, pada hari Senin Tanggal 25 Juni 2018 Pukul 10.30 WIB

${ }^{11}$ Hans Kelsen, Teori Umum Tentang Hukum dan Negara, (Bandung: Nusa Media, 2006), 95. 
Perumahan mengenai tanggung jawab kepada konsumen yaitu pada PT. Najah Bintang Sejahterah, bahwa Pihak pengembang Perumahan berjanji akan bertanggung jawaban atas Pembangunan rumah konsumen hanya sebatas yang diperjanjikan yang tertulis saja jika tidak ada diperjanjikan pengembang Perumahan tidak bisa melaksanakannya.

Selain itu adanya tanggung jawab dari pihak pengembang yang tidak terlaksana dikarenakan adanya masalah teknis biaya pekerja pembangunan rumah yang protes meminta kenaikan biaya pekerja.

Pihak Pengembang Perumahan akan bertanggung jawab kepada konsumen setelah biaya-biaya angsuran pelunasan diberikan oleh konsumen kepada pengembang Perumahan.

Pihak pengembang Perumahan memiliki kendala karena keterbatasan biaya dan tidak mempunyai biaya lagi untuk membangun rumah konsumen yang belum dibangun.

Pihak pengembang Perumahan berjanji dan meminta waktu akan tetap bertanggung jawab untuk melaksanakan kewajibannya kepada konsumen.

Pihak Perumahan berjanji akan bertanggung jawab kerugian yang diderita konsumen, namun konsumen harus bersabar dan waktu kepada pihak Perumahan.

Pihak pengembang Perumahan berjanji akan memasukkan fasilitas listrik ke Perumahan yang belum dipasang listrik. ${ }^{12}$

Dalam hal ini tanggung jawab pengembang perumahan dari permasalahan pembangunan rumah tersebut di atas dikaitkan dengan Pasal 134 Undang-Undang Perumahan dan Permukiman. Disebutkan bahwa Setiap orang dilarang menyelenggarakan pembangunan Perumahan, yang tidak membangun sesuai dengan kriteria, spesifikasi, persyaratan, prasarana, sarana, dan utilitas

${ }^{12}$ Defizul, Wawancara, pada hari Selasa Tanggal 17 Juli 2018 pukul 14.00 WIB. umum yang diperjanjikan. Masih Banyaknya pelanggaran yang dilakukan oleh pihak pengembang Perumahan seharusnya menjadi tanggung jawab pengembang perumahan, bentuk tanggung jawab yang harus dilakukan pengembang perumahan dari pelanggaran lain yang dilakukan oleh pengembang adalah menyangkut pelanggaran hak-hak konsumen perumahan.

Sebagaimana Pada Pasal 151 Ayat (1) UUPKP menjelaskan bahwa:

"Setiap orang yang menyelenggarakan pembangunan perumahan yang tidak membangun perumahan sesuai dengan kriteria, spesifikasi, persyaratan, prasarana, sarana, dan utilitas umum yang diperjanjikan sebagaimana dimaksud dalam Pasal 134, dipidana dengan pidana denda paling banyak Rp5.000.000.000,- (lima miliar rupiah)". dan

Pada Ayat (2) dikatakan bahwa Selain pidana sebagaimana dimaksud pada ayat (1) pelaku dapat dijatuhi pidana tambahan berupa membangun kembali perumahan sesuai dengan kriteria, spesifikasi, persyaratan, prasarana, sarana, dan utilitas umum yang diperjanjikan".

Undang-Undang tentang Perumahan dan Kawasan Permukiman menegaskan prinsip perlindungan konsumen yang mulai mengenal dan didasarkan prinsip tangggung jawab mutlak (absolute responsibility) bahwa prinsip ini adalah suatu jawaban atas konsep tanggung jawab pelaku usaha dalam hal ini adalah pihak pengembang perumahan yang didasarkan pada adanya suatu hubungan kontrak antara pelaku usaha dan konsumen. Pemikiran utama yang mendasari prinsip tanggung jawab mutlak adalah bahwa pihak pelaku usaha memiliki posisi yang lebih kuat dibandingkan pihak konsumen untuk mengetahui dan mengawasi produk barang dan/atau jasa. Pelaku usaha memiliki kemampuan yang lebih besar untuk mengawasi objek barang. 
Tanggung jawab oleh pelaku usaha atau pengembang Perumahan jika barang dan/atau jasa yang cacat telah sampai pada konsumen dan mengakibatkan kerugian bagi konsumen adalah memberikan ganti rugi atas kerusakan atau kerugian konsumen akibat barang dan/atau jasa yang dihasilkan atau diperdagangkan. Tanggung jawab pelaku usaha selain tanggung jawab mutlak (strict product liability) juga bertanggung jawab terhadap contractual liability (tanggung jawab yang didasarkan pada perjanjian). Contractual liability (tanggung jawab yang didasarkan pada perjanjian).

Bahwa adanya prinsip tanggung jawab menyatakan seseorang baru dapat dimintakan pertanggung jawabannya secara hukum jika ada unsur kesalahan yang dilakukannya. Berdasarkan hasil penelitian yang dilakukan bahwa tidak adanya terlaksananya janji yang telah disepakati serta tidak adanya pertanggung jawaban dari pihak pengembang perumahan. Di mana tidak terjadinya perbuatan yang telah diperjanjikan di dalam perjanjian antara pengembang dengan konsumen dan pihak pengembang melakukan kesalahan tidak melaksanakan perjanjian yang telah disepakatinya yang mana tidak membangun rumah yang telah disepakati. Sehingga hal tersebut menimbulkan kerugian bagi konsumen sedangkan pihak pengembang tetap tidak melaksanakan tanggung jawabnya jelas melanggar dan bertentangan dengan hukum dan jelas melanggar Peraturan Perundang-Undangan.

\section{PENYELESAIAN JIKA PIHAK PENGEMBANG PT. NAJAH BINTANG SEJAHTERA TIDAK MEMENUHI KEWAJIBANNYA.}

Dalam suatu perjanjian berdasarkan kesepakatan bersama maupun ditentukan oleh pihak pengembang perumahan yang telah dimengerti dan telah ditandatangani oleh para pihak, biasanya di dalam perjanjian memuat suatu pasal tersendiri yang menyatakan cara bagaimana melakukan suatu penyelesaian atas suatu perselisihan atau sengketa yang timbul akibat dari suatu permaslahan. Pelaksanaan perjanjian jual beli haruslah dilaksanakan dengan baik sesuai dengan hak dan kewajiban masing-masing pihak dalam perjanjian tersebut, akan tetapi tidak selamanya para pihak melaksanakan perjanjian itu dengan baik. Akibat tidak terpenuhinya suatu prestasi dengan baik oleh para pihak dapat menimbulkan terjadinya suatu ingkar janji (Wanprestasi) terhadap perjanjian yang telah disepakati. Bagian upaya hukum pada penyelesaian sengketa didalam perjanjian merupakan bagian ketentuan atau klausul khusus yang diperjanjikan oleh para pihak didalam suatu perjanjian atas kesepakatan kedua belah pihak itu sendiri yang merupakan bagian acsidentalia dalam suatu kontrak, tetapi tidak semua pihak memahami dan mengerti bagian acsidentalia tersebut, kurangnya dan ketidaktahuan pemahaman pengetahuan para pihak terhadap pentingnya bagian upaya penyelesaian tersebut sehingga terjamin bagi para pihak apabila terjadi suatu sengketa.

Pada kenyataannya hal tersebut dikaitkan dengan praktek pada pengembang PT. Najah Bintang Sejahtera di kota pekanbaru dengan konsumen-konsumennya dalam isi perjanjiian jual beli rumah yang dibuat secara di bawah tangan oleh pihak pengembang dengan tidak mencantumkan klausul tentang Penyelesaian sengketa apabila terjadi sengketa konsumen dengan pengembang perumahan. Hal tersebut benar-benar terjadi suatu sengketa. Berdasarkan penelitian, faktor-faktor penyebab tersebut aadanya ketidakpahaman pengembang perumahan dan konsumen terhadap mekanisme jual beli rumah. Selain itu adannya ketidakpahaman konsumen terhadap isi kontak dan produk hukum kontrak yang sebagaimana telah diatur oleh perundangundangan. 
Terkait dengan ketidakpahaman konsumen terhadap produk hukum yang melindungi kegiatannya, bahwa Muhammad Syaifuddin menjelaskan sebab terjadinya sengketa dari kotrak, faktor-faktor tersebut adalah para pihak kurang cermat atau kurang hati-hati ketika melakukan perundingan pendahuluan; para pihak kurang mempunyai wawasan hukum, khususnya hukum kontrak; para pihak tidak mempunyai keahlian untuk mengkontruksiikan norma-norma hukum kontrak yang pasti,adil dan efesien; para pihak kurang mampu mencermati resiko yang potensial terjadi, sehingga tidak terumuskan dalam kontrak; para pihak tidak jujur, dalam arti masih menyembunyikan hal-hal yang seharusnya dikemukakan oleh pihak yang satu kepada pihak yang lain; dan para pihak membiarkan secara sadar atau tidak sadar potensi persoalan hukum yang dapat terjadi dikemudian hari. ${ }^{13}$

Upaya penyelesaian sengketa dalam bisnis properti seperti dua sisi mata uang pada satu sisi bisa dikatakan bahwa tidak ada satu pun pelaku bisnis properti maupun konsumen menginginkan sengketa. Tetapi disisi lain pemahaman terhadap hukum penyelesaian sengketa apabila pihak pelaku usaha atau pengembang tidak melaksanakan kewajibannya maka penyelesaian hukum juga diperlukan, tidak hanya untuk mencegah sengketa saja maupun menyelesaikan sengketa yang sudah terlanjur terjadi. Sebagaimana diatur dalam Pasal 148 Undang-Undang Perumahan dan Kawasan Permukiman bahwa:

1. Dalam hal penyelesaian sengketa melalui musyawarah untuk mufakat tidak tercapai, pihak yang dirugikan dapat menggugat melalui pengadilan yang berada di lingkungan pengadilan umum atau di luar pengadilan berdasarkan pilihan sukarela

${ }^{13}$ Muhammad Syaifuddin, Hukum Kontrak Memahami Kontrak Dalam Perspektif Filsafat, Teori, Dogmatik, dan Praktisi Hukum, Mandar Maju, Bandung, 2012 para pihak yang bersengketa melalui alternatif penyelesaian sengketa.

2. Penyelesaian sengketa di luar pengadilan sebagaimana dimaksud pada ayat (1) dilakukan melalui arbitrase, konsultasi, negosiasi, mediasi, konsilisiasi, dan/atau penilaian ahli sesuai dengan ketentuan peraturan perundang-undangan.

3. Penyelesaian sengketa di luar pengadilan sebagaimana dimaksud pada ayat (2) tidak menghilangkan tanggung jawab pidana.

Seperti pada permasalahan sengekta yang terjadi pada konsumen Perumahan Najah Dwi Sejahtera dengan pihak pengembang, PT. Najah Bintang Sejahtera di kota Pekanbaru Berdasarkan hasil penelitian yang dilakukan bahwa di dalam perjanjian jual beli rumah konsumen dengan pengembang PT. Najah Bintang Sejahtera tidak ada menyebutkan tentang klausul apabila terjadi suatu sengketa upaya penyelesaian sengketa atau penyelesaian perselisihan antara konsumen dengan pihak pengembang PT. Najah Bintang Sejahtera sehingga dari isi perjanjian tersebut sangat lemah dan merugikan konsumen apabila terjadi inkar janji (wanprestasi) dari pihak pengembang perumahan.

Menurut beberapa ahli ada beberapa kelemahan yang sering ditemukan dalam upaya penyelesaian sengketa yang dilakukan dengan musyawarah di antaranya adalaha manakala para pihak berkedudukan tidak seimbang, salah satu pihak kuat, yang lain lemah. Dalam keadaan ini pihak yang kuat dapat melaksanakan kehendaknya kepada pihak yang lemah. Selain itu, proses berlangsungnya negosiasi sering kali berjalan dengan lambat dan membutuhkan waktu yang lama. Di samping karena tingkat kerumitan permasalahan, lambatnya penyelesaian sengketa yang dilakukan secara musyawarah bisa juga disebabkan oleh karena faktor kesengajaan dari salah satu pihak yang bersengketa. Manakala suatu pihak terlalu 
keras pendiriannya, dapat menyebabkan proses musyawarah tidak berjalan kondusif. ${ }^{14}$

Namun dari hal tersebut di atas, upaya yang dapat dilakukan konsumen apabila pihak konsumen dengan pengembang PT. Najah Bintang Sejahtera terjadi suatu permasalahan dan timbul suatu sengketa maka konsumen dapat melakukan upaya penyelesaian perselisihan dengan cara sebagaimana yang telah diatur pada Praturan Perundang-Undangan.

\section{Penyelesaian Sengketa Dengan Musyawarah.}

Musyawarah yang berarti berunding atau berembuk menurut istillah pengertian musyawarah adalah perundingan bersama antara dua orang atau lebih untuk mendapatkan keputusan yang terbaik yang mana mengambil keputusan bersama dalam memecahkan suatu persoalan atau permasalahan yang sedang dihadapi atau diselesaikan dengan saling menghargai satu sama lain. Penyelesaian sengketa konsumen dengan pengembang perumahan melalui musyawarah merupakan tahap pertama yang harus dilakukan para pihak sebelum melakukan upaya penyelesaian sengketa secara litigasi atau non litigasi. Para pihak yang bersengketa diharuskan untuk melakukan upaya penyelesaian sengketa melalui musyawarah.

Ketentuan tersebut dapat kita lihat Sebagaimana diatur didalam Pasal 147 UU PKP bahwa Penyelesaian sengketa di bidang perumahan terlebih dahulu diupayakan berdasarkan musyawarah untuk mufakat. Musyawarah dalam sengketa konsumen biasanya dilakukan antara konsumen dengan pengembang perumahan dimana tempat dan kedudukan untuk musyawarah disepakati oleh para pihak sebgaimana diamanatkan pada Pasal 148 UU PKP bahwa:

${ }^{14}$ Huala Adolf, Hukum Penyelesaian Sengketa Penanaman Modal, Cetakan Pertama, Keni Media, Bandung, 6-7.
1. Dalam hal penyelesaian sengketa melalui musyawarah untuk mufakat tidak tercapai, pihak yang dirugikan dapat menggugat melalui pengadilan yang berada di lingkungan pengadilan umum atau di luar pengadilan berdasarkan pilihan sukarela para pihak yang bersengketa melalui alternatif penyelesaian sengketa.

2. Penyelesaian sengketa di luar pengadilan sebagaimana dimaksud pada ayat (1) dilakukan melalui arbitrase, konsultasi, negosiasi, mediasi, konsilisiasi, dan/atau penilaian ahli sesuai dengan ketentuan peraturan perundang-undangan.

Sebenarnya konsumen mempunyai perlindungan hukum dan biasanya melakukan upaya penyelesaian sengketa dengan mengajukan tuntutan yang dirugikan dan perjanjian jual beli rumah merupakan salah satu bukti untuk konsumen ketika membeli rumah yang belum jadi dibangun. Bahwa Perjanjian itu sendiri dibuat karena pengembang menawarkan rumah yang belum jadi sehingga perlu adanya jaminan hukum bagi kedua belah pihak. Klausul perjanian jual beli dalam prakteknya memang sudah baku dan dibuat sendiri oleh pengembang perumahan, tetapi pengembang tidak boleh sewenang-wenang dalam membuat isi dari PPJB karena ada pedoman aturan dari pemerintah. Pedoman dari PPJB adalah Keputusan Menteri Negara Perumahan Rakyat Nomor 09/KPTS/M/1995 tentang Pedoman Pengikatan Jual Beli Rumah.

Terkait dengan ketentuan penyerahan tanah dan bangunan, Keputusan Menteri ini menentukan bahwa pembeli berhak membatalkan perjanjian jika:

1. Pihak Penjual tidak dapat menyerahkan Tanah dan Bangunan Rumah beserta hakhak yang melekat, tepat waktu yang diperjanjikan, dan Pembeli telah selesai kewajibannya untuk membayar harga Tanah dan Bangunan tersebut. 
2. Pihak Penjual menyerahkan Tanah dan Bangunan Rumah yang tidak cocok dengan Gambar Denah, dan Spesifikasi Teknis Bangunan yang telah ditetapkan bersama dan menjadi lampiran dalam Pengikatan Jual beli.

3. Apabila keadaan yang dimaksud dalam butir a dan b angka IX tersebut terjadi maka perjanjian menjadi batal, dan Penjual wajib membayar uang yang telah diterima, ditambah dengan denda, bunga, dan biayabiaya lainnya sesuai dengan ketentuan yang berlaku menurut hukum.

4. Pembeli tidak dapat memenuhi dan atau tidak sanggup meneruskan kewajibannya untuk membayar harga Tanah dan Bangunan Rumah sesuai dengan yang diperjanjikan.

5. Pembeli tidak dapat memenuhi kewajibannya untuk membayar cicilan kepada Bank Pemberi Kredit Pemilikan Rumah (KPR) sesuai dengan syarat-syarat Akta Perjanjian Kredit.

6. Pembeli mengundurkan diri atau membatalkan transaksi jual beli Tanah dan Bangunan Rumah karena suatu sebab atau alasan apapun juga.

Apabila keadaan sebagaimana dimaksud dalam butir $\mathrm{d}$, e, dan $\mathrm{f}$ angka IX tersebut terjadi dalam hal pembayaran atas Tanah dan Bangunan Rumah belum mencapai 10\% (sepuluh presen) maka keseluruhan pernbayaran tersebut menjadi hak pihak Penjual. Dalam hal pembayaran harga Tanah dan Bangunan Rumah yang dilakukan pihak Pembeli melebihi 10\% (sepuluh prosen) maka pihak Penjual berhak memotong 10\% (sepuluh prosen) dari jumlah total harga Tanah dan Bangunan Rumah dan sisanya wajib dikembalikan kepada pihak Pembeli.

Berdasarkan dari ketentuan yang di muat di atas, diketahui bahwa konsumen Perumahan Najah Dwi Sejahterah, PT. Najah Bintang Sejahtera mempunyai cara untuk menuntut pengembang mengembalikan uangnya jika pengembang tidak dapat kejelasan dan tidak menyerahkan Bangunan Rumah tepat waktu atau apabila Penjual menyerahkan Tanah dan Bangunan Rumah yang tidak sesuai dengan Spesifikasi Teknis Bangunan yang telah ditetapkan. Akan tetapi dalam kenyataannya, tetap saja pihak pengembang berhasil melepaskan diri dari tanggung jawabnya berdasarkan klausula yang dimuatnya dalam perjanjian. Padahal jika pengembang mematuhi dengan konsisten ketentuan Keputusan Menteri Negara Perumahan Rakyat Nomor 09/KPTS/M/1995 tentang Pedoman Pengikatan Jual Beli Rumah, pengembang tentu kena sanksi sesuai ketentuan Bagian IX angka 1 huruf c Keputusan Menteri Negara Perumahan Rakyat Nomor 09/KPTS/M/1995, yaitu harus mengembalikan uang pokok, bunga, denda dan biaya-biaya lainnya kepada pembeli.

Permasalahan tersebut diatas pada Konsumen Perumahan Najah Dwi Sejahterah, baik orang perseorangan, badan hukum, masyarakat dan/atau pemerintah dan/atau instansi apabila merasa dirugikan dapat menggugat pengembang Perumahan baik melalui peradilan umum (litigasi) atau luar peradilan (non litigasi), apabila musyawarah yang telah dijalani atau dilakukan tidak menghasilkan sesuatu yang dihendaki. Penyelesaian sengketa di luar pengadilan (non litigasi) menurut Pasal 148 Ayat (2) UU PKP dilakukan melalui arbitrase, konsultasi, negosiasi, mediasi, konsilisiasi, dan/atau penilaian ahli sesuai dengan ketentuan Peraturan Perundang-Undangan dan dipertegas dengan Pasal 3 huruf (a) Kepmenperindag No. 350/MPP/Kep/12/2001 tentang Pelakanaan Tugas dan Wewenang Badan Penyelesaian Sengketa Konsuemen (BPSK) melalui lembaga yang berwenang, yaitu melalui Badan Penyelesaian Sengketa Konsumen (BPSK) dengan menggunakan mekanisme melalui konsilidasi, mediasi, atau arbitrase. 


\section{Penyelesaian Sengketa Melalui Tindak Pidana.}

Upaya pidana dapat ditempuh oleh konsumen dengana pelaporan tindak pidana. Konsumen yang dapat dilakukan dalam hal penyelesaian dengan upaya pidana dapat mengupayakan dengan upaya penyelesaian sebagaimana diatur pada UU PKP adanya ketentuan tentang pidana yaitu Pasal 151, bahwa setiap orang yang menyelenggarakan pembangunan perumahan, yang tidak membangun perumahan sesuai dengan kriteria, spesifikasi, persyaratan, prasarana, sarana, dan utilitas umum yang diperjanjikan sebagaimana dimaksud dalam Pasal 134, dipidana dengan pidana denda paling banyak Rp5.000.000.000,00 (lima miliar rupiah). Selain pidana sebagaimana dimaksud pada ayat (1) pelaku dapat dijatuhi pidana tambahan berupa membangun kembali perumahan sesuai dengan kriteria, spesifikasi, persyaratan, prasarana, sarana, dan utilitas umum yang diperjanjikan.

Menurut Pasal 9 UUPK pengembang Perumahan yang melakukan penyelewengan tersebut diancan hukuman pidana penjara paling lama 5 (lima) tahun atau pidana denda paling banyak Rp 2.000.000.000 (dua milyar rupiah). Ancaman pidana lain bagi pengembang yang membangun proyek tidak sesuai dengan kriteria, spesifikasi, dan persyaratan yang dijanjikan dan juga diatur dalam Pasal 134 jo Pasal 151 Undang-Undang Nomor 1 tahun 2011 tentang Perumahan dan Kawasan Pemukiman yaitu denda maksimal Rp 5 miliar. Selain berupa denda, sanksi bagi pengembang Perumahan adalah sanksi administratif seperti ditulis dalam Pasal 150 UU Perumahan. Sanksinya mulai dari peringatan tertulis, pencabutan izin usaha, hingga penutupan lokasi, Itu tadi penjelasan mengenai bisakah konsumen menuntut pengembang Perumahan.

\section{PENYELESAIAN SENGKETA DALAM HUKUM ISLAM}

Dalam tradisi Islam, setidaknya dikenal tiga sistem dalam menyelesaikan sengketa atau perselisihan yaitu; Perdamaian dengan Musyawarah Mufakat (as-shulb), Arbitrase (at-tabkim) dan Peradilan melalui upaya Tindak Pidana (al-qadha). ${ }^{15}$

\section{Perdamaian (as-Sbulb)}

Perdamaian adalah jalan yang diambil untuk menyelesaikan sengketa dengan cara musyawarah untuk menemukan solusi bagaimana perselisihan yang terjadi diantara kedua pihak dapat diatasi dengan mengambil titik terang untuk saling ridha dan ikhlas. Damai merujuk pada peran yang ditampilkan pihak ketiga sebagai mediator dalam menjalankan tugasnya menengahi dan menyelesaikan sengketa antara para pihak, ini juga bermakna perdamaian ini berada di posisi tengah yang sifatnya netral dan tidak memihak dalam menyelesaikan sengketa.

Dalam Islam dibenarkan bahwa menjalin hubungan baik secara damai adalah suatu kenikmatan (rahmat). Dalam surat AlHujarat ayat 10:

"Orang-orang beriman itu sesungguhnya
bersaudara. Sebab itu damaikanlah
(perbaikilah bubungan) antara kedua
saudaramu itu dan takutlah terhadap Allah,
supaya kamu mendapat rahmat."
Melaksanakan al-Shulh harus memenuhi beberapa rukun, yaitu:

1. Adanya ara pihak yang bersengketa yaitu orang yang cakap dalam hukum.

2. Adanya objek persengketaan, yaitu suatu hal yang menjadi titik permasalahan.

3. Adanya lafadz pernyataan damai (ijab kabul), ijab kabul sebagai ungkapan perjanjian atau persetujuan kedua belah pihak.

${ }^{15}$ Maskufa, "Penyelesaian Sengketa Perjanjian Syariah Pada Lembaga Keuangan Suariah", Al-Iqtishad, Vol. V., No. 1, 2013, . 119-122. 


\section{Arbitrase (at-Tabkim)}

Kata tabkim secara etimologis berarti menjadikan seseorang sebagai pencegah suatu sengketa(hakam). Tahkim yaitu tempat bersandarnya dua orang yang bersengketa kepada seseorang yang mereka tunjuk sebagai penengah (orang yang diridhai) keputusannya untuk menyelesaikan pertikaian para pihak yang bersengketa tersebut.

Dalil Alquran tentang arbitrase Syariah QS. An-Nisa ayat 35;

"Dan jika kamu khawatirkan ada
persengketaan anatara keduanya, maka
kirimlah seorang hakam dari keluarha laki-
laki dan seorang hakam dari keluarga
perempuan. Jika kedua orang hakam itu
bermaksud mengadakan perbaikan, niscaya
Allah memberi taufik kepada suami-istri itu.
Sesunggubnya Allah maha mengetahui lagi
maha mengenal."

Penyelesaian dengan cara arbitrase ini sah dilakukan sesuai dengan maksud adanya badan arbitase di Indonesia untuk kesejahteraan para masyarakat Indonesia. Telah berdiri lembaga Arbitrase Syariah Di Indonesia yaitu: Badan Arbitrase Nasional (BANI), lalu pada tanggal 21 Oktober 1993 Badan Arbitrase Muamalat Indonesia (BAMUI) yang di bentuk oleh MUI (majlis Ulama Indonesia). Kemudian pada tanggal 24 Desember 2003 berdiri Badan Arbitrase Syariah Nasional (BASYARNAS) sebagai ganti BAMUI yang berwenang menyelesaikan sengketa perdata secara Islam, dan terakhir Badan Arbitrase Pasar Modal Indonesia (BAPMI).

\section{Pengadilan (al-Oadha)}

Secara etimologis qadha bermakna memutuskan dan menetapkan, sedangkan secara terminologis, qadha adalah lembaga peradilan yang bertugas untuk menyampaikan keputusan hukum yang mengikat. Biasanya cara ini digunakan apabila kedua belah pihak belum berhasil menemukan titik terang dalam penyelsaian sengketa, mesikpun sudah menggunakan jalan perdamaian dan arbitrase. Dasar hukum tentang cara penyelesaian sengketa melalui lembaga peradilan ini terdapat dalam QS. Al-Baqarah ayat 213 yang berbunyi;

"Manusia itu adalah umat yang satu. (setelab timbul perselisihan), maka Allah mengutus para nabi, sebagai pemberi perigatan dan Allah menurunkan bersama mereka kitab yang benar, untuk memberi keputusan dia antara manusia tentang perkara yang mereka perselisibkan. Tidaklah berselisib tentang kitab itu melainkan orang yang telah didatangkan kepada mereka kitab, yaitu setelah datang kepada mereka keteranganketerangan yang nyata, karena dengki antara mereka sendiri. Maka Allah memberi petunjuk orang-orang yang beriman kepada kebenaran tentang hal yang mereka perselisibkan itu dengan kehendak-Nya. Dan Allah selalu memberi petunjuk orang yang diehendaki-Nya kepada jalan yang lurus."

\section{KESIMPULAN}

Berdasarkan uraian pembahasan di atas, maka dapat disimpulkan pertama, Proses transaksi jual beli rumah antara konsumen dengan PT. Najah Bintang Sejahtera di Kota Pekanbaru diawali dengan kesepakatan melakukan perjanjian jual beli rumah secara dibawah tangan antara pengembang dengan konsumen yang perjanjiannya dibuat oleh pengembang Perumahan Najah Dwi Sejahtera, sistem pembayaran dengan cara cash bertahap.

Kedua, Pertanggung jawaban pengembang terhadap perjanjian jual beli rumah antara konsumen dengan pengembang PT. Najah Bintang Sejahtera di Kota Pekanbaru bahwa hingga sampai sekarang kenyataanya tidak ada pertanggung jawaban dari pihak pengembang dan pembangunan rumah tidak terselesaikan.

Ketiga, Upaya konsumen dapat menempuh upaya penyelesaian dengan melalui musyawarah terlebih dahulu dengan pihak pengembang perumahan namun tidak 
mendapatkan hasil, maka salah satu konsumen melakukan upaya pengaduan kepada Badan Penyelesaian Sengketa Konsumen (BPSK) secara nonlitigasi sebagai upaya mediasi, konsiliasi, dan arbritase, dan konsumen tidak mengetahui lagi bagaimana upaya yang harus dilakukan dan sebenarnya apabila tidak tercapai konsumen dapat melakukan secara litigasi ke peradilan umum dengan upaya gugatan secara perdata atau upaya pidana dengan cara pelaporan kepada pihak yang berwenang oleh peraturan PerundangUndangan yaitu pihak penyidik kepolisian dengan upaya pidana. 


\section{DAFTAR KEPUSTAKAAN}

Ali, Zanuddin, Metode Penelitian Hukum, Sinar Grafika, Jakarta, 2014.

Fuandy, Munir, Pengantar Hukum Bisnis Menata Bisnis Modrn di Era Global, Cetakan IV, Citra Aditya Bakti, Bandung, 2013.

Hans Kelsen, Teori Umum Tentang Hukum dan Negara, Nusa Media, Bandung, 2006.

Huala Adolf, Hukum Penyelesaian Sengketa Penanaman Modal, Cetakan Pertama, Keni Media, Bandung.

Kitab Undang-Undang Hukum Perdata.

Keputusan Menteri Negara Perumahan Rakyat Nomor 09/KPTS/M/1995 tentang Pedoman Pengikatan Jual Beli Rumah.

Maskufa, "Penyelesaian Sengketa Perjanjian Syariah Pada Lembaga Keuangan Suariah", AlIqtishad, Vol. V., No. 1, 2013.

Miru, Ahmadi dan Sutarman Yudo, Hukum Perlindungan Konsumen, PT. Raja Grafindo Persada, Jakarta, 2011.

Sadar, M., Moh. Taufik Makarao, Habloel Mawardi, Hukum Perlindungan Konsumen di Indonesia, Akademia, Jakarta Barat, 2012.

Shofie, Yusuf, Perlindungan Konsumen dan Instrumen Hukumnya, Bandung, PT. Citra Aditya Bakti, 2008.

Syaifuddin, Muhammad, Hukum Kontrak - Memahami Kontrak Dalam Perspektif Filsafat, Teori, Dogmatik, dan Praktisi Hukum, Mandar Maju, Bandung, 2012.

Undang-Undang Nomor 1 Tahun 2011 tentang Perumahan dan Kawasan Permukiman.

Undang-Undang Nomor 8 Tahun 1999 tentang Perlindungan Konsumen.

Wijaya, Andika dan Wida Peace Ananta, Hukum Bisnis Properti di Indonesia, PT. Grasindo, Jakarta, 2017. 